\title{
THE EFFECT OF EWOM, EASE OF USE AND TRUST ON PURCHASE DECISIONS (STUDY ON TOKOPEDIA APPLICATION USERS)
}

\author{
Mailal Badir* and Anik Lestari Andjarwati \\ Universitas Negeri Surabaya, Indonesia
}

\begin{abstract}
The purpose of this study is to determine the effect of e-WOM, convenience, and trust in purchasing decisions. The development of internetbased trading systems or e-commerce changes the patterns of consumer behavior from conventional shopping to shopping digitally or online. The sample in this study was 200 respondents of Tokopedia users. The analysis uses multiple regression analysis. The results showed there was no significant effect of the eWOM variable on purchasing decisions, and there was a substantial influence on the easiness and trust variables on buying decisions.
\end{abstract}

Keywords: E-WOM, Ease of use, Trust, E-commerce, Purchase decisions

Submitted: 9 May 2020; Revised: 15 May 2020; Accepted: 31 May 2020

*Corresponding author : mailalbadir16080574088@mhs.unesa.id

DOI: $10.24252 /$ minds.v7i1.13715

ISSN-E: 2597-6990

ISSN-P: 2442-4951 


\section{INTRODUCTION}

The development of internet-based trading systems or e-commerce is changing the pattern of consumers from everyday purchases by visiting physical stores to digital or online shopping. The percentage of e-commerce industry has increased by $17 \%$ in the last ten years, with the total number of e-commerce businesses reaching 26.2 million units, and continuing (idea.or.id). The list of ecommerce players from the official site of Idea (Indonesian E-commerce Association) categorizes 47 e-commerce marketplace and inventories. From the list of top 10, e-commerce players in Indonesia are local e-commerces. Based on iprice.co.id data, Tokopedia as local e-commerce became the most visited ecommerce in 2018-2019. Based on the results of research conducted by topbrandaward.com in 2019, Tokopedia came in third place, defeated by Lazada and Shopee. This study aims to investigate Tokopedia users' purchase decisions related to several behavioral predictors.

The phenomenon in society today shows technological developments affect consumers to communicate. Word of mouth (WOM) accelerated by the use of the internet is referred to as electronic word of mouth (eWOM). The occurrence of eWOM is inseparable from the consumer experience of goods or services that have been consumed. According to (Hennig-Thurau et al., 2004), eWOM is a statement made by actual, potential or previous consumers about a product or company where this information is available to people or institutions via the internet. Zhang et al. (2010) state that when exchanging information through eWOM, consumers proceed with the evaluation of the product. Positive e-WOM can persuade potential customers and influence consumers' perceptions of product reviews or products recommended by other customers. According to the results of the study (Priansa, 2016) and (Sari et al., 2017) suggested that e-WOM affects purchasing decisions while (Wijaya \& Paramita, 2014) e-WOM does not significantly influence decisions purchase.

Ease of use is a term that represents the extent to which an innovation is considered not challenging to understand, learn, or operate (Haryanto, 2015). Davis (1989) defines ease of use as the level at which someone believes that technology can be easily used. The indirect influence on purchasing decisions through the perception of ease because the more comfortable the technology is used, the more useful it is. Some researches reveal that ease has a significant positive effect on purchasing decisions (Ardyanto et al., 2015; Kore et al., 2018; Pratama et al., 2019; Suhardi \& Taufik, 2018).

Due to the inherent nature of Internet shopping, consumers will always experience some level of risk. In essence, they make bets about the uncertainty of the future and the free actions of others (e.g., potentially trustworthy Web vendors, hackers, and unknown new technologies). In these uncertain situations, when consumers have to act, trust comes into play as a solution for the specific problems of risk (Kim et al., 2008). When someone shopping online, the main thing that becomes a consideration of a buyer is whether they believe in the website and sellers. Several research results reveal that trust has a significant positive effect on consumer purchasing decisions (Chin et al., 2009; Wang, Chen, \& Jiang 2009; Kore et al., 2018; Sfenrianto et al., 2018). 
This study uses not only the eWOM but also the ease of use and trust in purchasing decisions. This research tested all predictors to buying decisions in one go. Uniquely, we found a non-significant effect of eWOM to purchase decisions. This finding contributed to the pool of studies that find otherwise. Expected research results can be (1) a reference for the development of knowledge in the field of marketing management related to online purchasing decisions, (2) the next research reference about the influence of e-WOM, convenience, and confidence in online purchasing decisions.

\section{THEORETICAL REVIEW}

\section{Purchase Decision}

According to (Suhari, 2008), the decision to buy online is a process of a consumer in using internet media separately to purchase a product or service that begins with the emergence of consumer awareness of information or product that can be obtained from the internet. (Devaraj et al., 2003) stated that the purchase decision is a purchasing procedure carried out by consumers with the application procedure of electronic media because it has a larger utility-scale. There are five stages of the decision-making process according to (Turban et., al., 2015: 408), namely: (1) Problem recognition occurs when a consumer is faced with a gap between the current state and the desired state. (2) Information Search. After recognizing their needs, consumers will look for information about how to fulfill those needs. Consumers seek information through several sources. (3) Evaluation of alternatives, consumers evaluate all information obtained. Information is needed to rank the criteria for making a final choice. (4) Purchasing and shipping make final purchase choices, arrange payment and delivery, purchase guarantees, and so on. (5) Post-purchase behavior, evaluation of product uses, and consumers will experience several levels of satisfaction or dissatisfaction. If the customer is satisfied with the product and service, loyalty will increase and repeat purchases will occur.

$e-W O M$

According to (Hennig-Thurau et al., 2004), E-Wom refers to any efforts made by potential or actual old customers to highlight the positive or negative attributes of a product, company, or online platform. Meanwhile, (Sari et al., 2017) mention that electronic word of mouth offers a variety of ways to exchange information, many of which are anonymous or confidential. Several researchers examined the effect of e-WOM on purchasing decisions with the result that eWom had a significant positive impact on buying decisions (Sari et al., 2017; Priansa, 2016; Chen, 2012; Senecal \& Nantel, 2004). Those findings are different from (Wijaya \& Paramita, 2014) that e-WOM does not affect purchasing decisions. Based on the theory and previous research, the hypothesis in this study is as follows:

H1: There is an influence of e-WOM on Purchasing Decision. 
Ease of Use

Turban et al. (2010: 18) states that the success of ease of use can affect the confidence of users of information systems that information systems are easy to understand, more flexible, and easy to operate, such as ease of use characteristics. Meanwhile, according to (Davis, 1989), ease of use is the level where someone believes that the use of specific systems can reduce one's efforts in doing or doing something. According to (Monisa, 2013), ease of use is a level of someone believing that the use of technology only requires a little effort. Ease means having no difficulty or does not need hard effort when using technology. The ease of use of this technology refers to the individual belief that information technology systems can facilitate their activities without much effort. Some researchers examine the effect of convenience on purchasing decisions with the result that ease affects purchasing decisions (Ardyanto et al., 2015; Suhardi \& Taufik, 2018; Pratama et al., 2019). Based on the theory and previous research, the hypothesis in this study is as follows:

H2: There is an influence of Ease on Purchasing Decision.

Trust

According to Sumarwan (2014: 165), consumer trust is consumer knowledge about an object, its attributes, and its benefits. According to Mowen and Minor (2002: 322), customer trust is all knowledge owned by customers and all decisions made by customers about the object, attributes, and benefits of a product or service. Meanwhile, according to (Moorman et al., 1992), trust is the availability of a person to depend on other parties involved in the exchange because he believes in that party, belief is a general expectation that someone has that comes from another party that is said to be reliable. Trust is trust in partner relationships. Furthermore, according to (McKnight et al., 2002), it represents consumer confidence in good intentions, integrity, and ability of sellers in a situation, the willingness of consumers to accept any risk and the willingness of consumers to provide information about themselves when conducting transactions through internet media. Several research results reveal that trust has a significant positive effect on consumer purchasing decisions (Chin et al., 2009; Sfenrianto et al., 2018; Kore et al., 2018) while according to (Wardoyo \& Andini, 2017) trust does not affect purchasing decisions. Based on these theories, the hypothesis in this study is as follows:

H3: There is an influence of trust on the purchase decision.

\section{METHODOLOGY}

Research design

This type of research design is conclusive research. This study aims to test the hypothesis and the causal relationship between e-WOM variables, ease, and trust in purchasing decisions: 


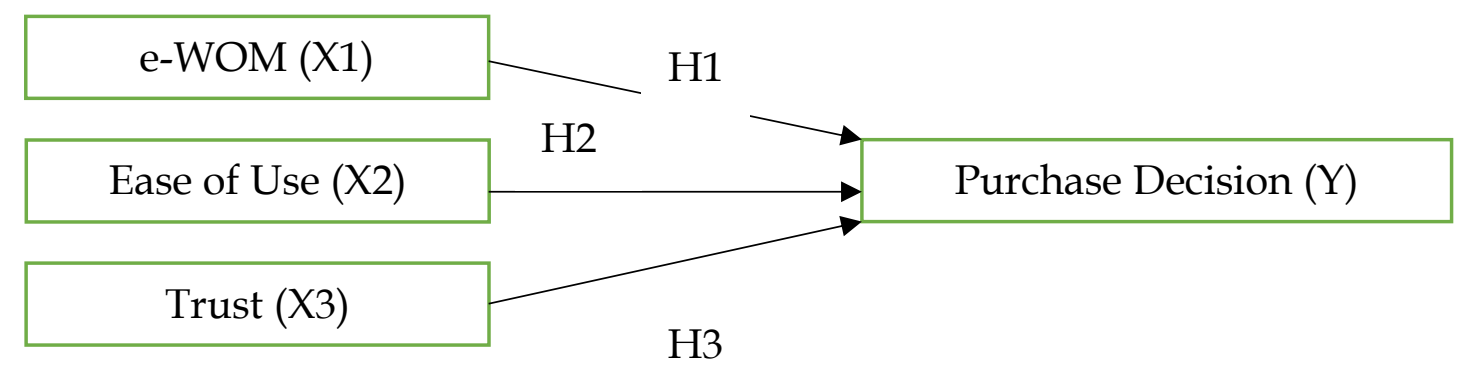

Figure 1. Research design

Operational definition

The following is the operational definition table used in this study and contains variables, indicators, and items.

Table 1. Variables, Indicators, and Items.

\begin{tabular}{ll}
\hline Variable Indicator & \multicolumn{1}{c}{ Item } \\
\hline eWOM & I foel the review on the Tokopedia \\
& application is clear \\
& I find the reviews on the Tokopedia \\
& application easy to understand \\
& I find the reviews on the Tokopedia \\
& application very helpful \\
& I feel that reviews on the Tokopedia \\
& application are trustworthy \\
& I feel that reviews on the Tokopedia \\
& application have reasons that support \\
& my opinion \\
& The number of reviews on the Tokopedia \\
& application shows that the product is \\
& popular. \\
ThOM Quantity number of reviews on the Tokopedia & app shows that the product has good \\
sales.
\end{tabular}




\begin{tabular}{|c|c|c|}
\hline Variable & Indicator & Item \\
\hline & & $\begin{array}{l}\text { Product ratings on the Tokopedia } \\
\text { application show that the product is } \\
\text { popular. }\end{array}$ \\
\hline & & $\begin{array}{l}\text { Product recommendations on the } \\
\text { Tokopedia application conclude that the } \\
\text { product has a good reputation. }\end{array}$ \\
\hline & Sender Expertise & $\begin{array}{l}\text { Someone who provides reviews on the } \\
\text { Tokopedia application } \\
\text { knowledgeable. }\end{array}$ \\
\hline & & $\begin{array}{l}\text { Someone who gives reviews on the } \\
\text { Tokopedia app has good judgment skills. }\end{array}$ \\
\hline & & $\begin{array}{l}\text { Someone who gives reviews on the } \\
\text { Tokopedia application is someone who is } \\
\text { experienced in their field. }\end{array}$ \\
\hline \multirow[t]{6}{*}{ Ease of use } & $\begin{array}{l}\text { Clear and } \\
\text { understandable }\end{array}$ & $\begin{array}{l}\text { The system on the Tokopedia application } \\
\text { is clear. }\end{array}$ \\
\hline & & $\begin{array}{l}\text { The Tokopedia application system is } \\
\text { easy to understand. }\end{array}$ \\
\hline & & $\begin{array}{l}\text { Easy Tokopedia application Tokopedia } \\
\text { application is easy to learn. }\end{array}$ \\
\hline & $\begin{array}{l}\text { Does not require } \\
\text { a lot of mental }\end{array}$ & $\begin{array}{l}\text { The system at Tokopedia doesn't require } \\
\text { much effort. }\end{array}$ \\
\hline & effort & $\begin{array}{l}\text { The Tokopedia application system is } \\
\text { easily accessible. }\end{array}$ \\
\hline & Ease of use & $\begin{array}{l}\text { I find the Tokopedia application easy to } \\
\text { use. }\end{array}$ \\
\hline \multirow[t]{4}{*}{ Trust } & Benevolence & $\begin{array}{l}\text { Promises made by Tokopedia can be } \\
\text { trusted. }\end{array}$ \\
\hline & & Tokopedia honesty no doubt. \\
\hline & & $\begin{array}{l}\text { Tokopedia keeps the promises they } \\
\text { make. }\end{array}$ \\
\hline & Integrity & $\begin{array}{l}\text { Tokopedia prioritizes quality service to } \\
\text { consumers. }\end{array}$ \\
\hline
\end{tabular}




\begin{tabular}{|c|c|c|}
\hline Variable & Indicator & Item \\
\hline & & $\begin{array}{l}\text { Tokopedia creates mutually beneficial } \\
\text { relationships with its customers. }\end{array}$ \\
\hline & & $\begin{array}{l}\text { Tokopedia prioritizes customer } \\
\text { satisfaction. }\end{array}$ \\
\hline & Ability & $\begin{array}{l}\text { Tokopedia has a good ability to secure } \\
\text { transactions. }\end{array}$ \\
\hline \multirow[t]{7}{*}{$\begin{array}{l}\text { Purchase } \\
\text { decision }\end{array}$} & $\begin{array}{l}\text { Information } \\
\text { Quality }\end{array}$ & $\begin{array}{l}\text { The Tokopedia application provides } \\
\text { excellent information about the items I } \\
\text { want to buy. }\end{array}$ \\
\hline & & $\begin{array}{l}\text { Overall, the Tokopedia application } \\
\text { provides useful information. }\end{array}$ \\
\hline & & $\begin{array}{l}\text { The Tokopedia application provides } \\
\text { enough information when a user tries to } \\
\text { make a transaction. }\end{array}$ \\
\hline & Security & $\begin{array}{l}\text { Tokopedia implements security } \\
\text { measures to protect users. }\end{array}$ \\
\hline & & $\begin{array}{l}\text { Feel safe with an electronic payment } \\
\text { system using the Tokopedia application. }\end{array}$ \\
\hline & & $\begin{array}{l}\text { Feel safe in making transactions on the } \\
\text { Tokopedia application. }\end{array}$ \\
\hline & Benefits & $\begin{array}{l}\text { Using the Tokopedia application is } \\
\text { convenient. }\end{array}$ \\
\hline
\end{tabular}

Source: data processed by researchers, 2020.

Sample

The population in this study is users of Tokopedia application with the following criteria: (1) 18 to 25 years in age. (2) made purchases in Tokopedia within the last one month. (3) Users of e mobile applications. The sample size used as many as 200 respondents by market testing studies. The sampling technique used in this study is non-probability sampling by relying on judgmental sampling. The flow of questionnaires online distribution: (1) Researchers make online questionnaires through Google form. (2) Researchers get a link that contains an online survey through Facebook, Instagram, Twitter, and WhatsApp. (3) The researcher selects respondents who have criteria as determined by the researcher. (4) Respondents who possess the appropriate measures will be given a link to answer the questionnaire. (5) Respondents are 
asked to identify other respondents. (6) The results of the respondents' answers are included in the response column in the researcher's email. (7) If the number of respondents meets the requirements, the next step of the researcher is to analyze and process data from the respondent's response. Data analysis techniques in this study using multiple regression analysis and t-test using SPSS 23 software.

\section{RESULTS}

The results of this study were conducted by distributing questionnaires online to respondents who are Tokopedia application users and made a purchase once in the past month. Respondents dominated respondents in this study with an age range of 22-25 years who were students because they are more attached to technology and digitally-literate.

Classic assumption test

Table 2. Classical Assumption Test Results

\begin{tabular}{|c|c|c|c|}
\hline No. & $\begin{array}{c}\text { Classical } \\
\text { Assumptions }\end{array}$ & Result & Conclusion \\
\hline 1. & Normality test & $\begin{array}{l}\text { The results of the } \\
\text { Kolmogorov-Smirnov } \\
\text { test (K-S) have a normal } \\
\text { distribution because the } \\
\text { significance value } \geq 0.05 \\
\text { is equal to } 0.200\end{array}$ & $\begin{array}{l}\text { Regression models } \\
\text { fulfill the } \\
\text { assumption of } \\
\text { normality. }\end{array}$ \\
\hline 2. & $\begin{array}{l}\text { Multicollinearity } \\
\text { Test }\end{array}$ & $\begin{array}{l}\text { Tolerance values in all } \\
\text { tables are higher than } \\
0.10 \text {, and for VIF values } \\
\text { for all variables } \leq 10 \text {. }\end{array}$ & $\begin{array}{l}\text { The model does } \\
\text { not occur } \\
\text { intolerance } \\
\text { between } \\
\text { independent } \\
\text { variables, or there } \\
\text { is no } \\
\text { multicollinearity. }\end{array}$ \\
\hline 3. & $\begin{array}{l}\text { Heteroscedasticity } \\
\text { Test }\end{array}$ & $\begin{array}{l}\text { Significance value on } \\
\text { each variable with a } \\
\text { residual more than } 0.05\end{array}$ & $\begin{array}{l}\text { No } \\
\text { heteroscedasticity } \\
\text { problems occur in } \\
\text { the model. }\end{array}$ \\
\hline
\end{tabular}

Source: SPSS 23 output, processed by researchers

Based on the table, this study has been supplemented with a classic assumption test, which then the researchers conducted a multiple linear regression analysis to determine the effect of e-WOM, convenience, and confidence in purchasing decisions. 
Multiple Linear Regression Analysis

Table 3. Result of Multiple Linear Regression Analysis

\begin{tabular}{lr}
\hline \multicolumn{1}{c}{ Variable } & Unstandardized Coefficients (B) \\
\hline Constant & 10.598 \\
eWOM & 0.024 \\
Ease of use & 0.451 \\
Trust & 0.256
\end{tabular}

Source: Processed Data of SPSS 23, 2020

$Y=10,598+0,024 X 1+0,451 X 2+0,256 X 3$

Where:

$\mathrm{Y}=$ Estimated value of the purchase decision variable

$\mathrm{X} 1=$ value of e-WOM variable

$\mathrm{X} 2=$ Value of convenience variable

$\mathrm{X} 3=$ value of the trust variable

Based on the table above, it can be seen the constant value in the multiple linear regression equation of 10.598, so if you do not use the e-WOM variable, convenience, and trust, then the purchase decision still occurs in Tokopedia of 10.598. The positive meaning of the constant value is that purchasing decisions on Tokopedia always happen even though consumers do not read or receive eWOM, do not feel convenience, or do not have trust. (1) The positive meaning shows that e-WOM (X1) and purchasing decisions have a direct relationship, so the better e-WOM given by Tokopedia users will strengthen the purchase decision. (2) Positive meaning shows that ease (X2) and purchasing decisions have a direct relationship, so that the more convenience when using Tokopedia, it will strengthen the purchase decision. (3) The positive meaning shows that trust (X3) and purchasing decisions have a direct relationship, so the better the trust given by Tokopedia, the stronger the buying decision.

Hypothesis Test

Table 4. Summary of Statistical Findings

\begin{tabular}{lccccc}
\hline \multicolumn{1}{c}{ Variable } & $\mathrm{R}^{2}$ & t-value & t-table & Sig. & Hypothesis \\
\hline eWOM & & 0.372 & & 0.711 & Rejected \\
Ease of Use & 0.299 & 5.891 & 1.65 & 0.000 & Accepted \\
Trust & & 4.141 & & 0.000 & Accepted \\
\hline
\end{tabular}

Source: Processed Data of SPSS 23, 2020 
Based on table 4 , it can be seen that the contribution value or adjusted $\mathrm{R}^{2}$ value for the independent variable is e-WOM, ease of use, and trust of the dependent variable, namely purchasing decisions (Y) of 0.299 or $30 \%$. This means that e-WOM, convenience, and trust have a portion of influence on purchasing decisions by $30 \%$. In contrast, the rest is influenced by other variables not included in the linear regression model.

Based on the table, the significance value of $0.711>0.05$. Then it is concluded that $\mathrm{H} 0$ is accepted, and $\mathrm{H} 1$ is rejected. It can be rejected because the e-WOM variable $(X 1)$ does not have a significant effect on purchasing decisions $(\mathrm{Y})$. Significance value of $0,000<0.05$. Then it is concluded that $\mathrm{H} 0$ is rejected, and $\mathrm{H} 1$ is accepted, so it can be considered an easy variable (X2), which does not have a significant influence on purchasing decisions (Y). T-count of X1 4.141>t-table 1.65 and the significance value of $0.000<0.05$. Then it is concluded that $\mathrm{HO}$ is rejected, and $\mathrm{H} 1$ is accepted, so it can be explained that the trust variable (X3) has a significant influence on purchasing decisions $(\mathrm{Y})$.

\section{DISCUSSION}

\section{Effect of e-WOM on purchasing decisions}

The results showed that there was no significant effect of e-WOM on purchasing decisions due to the t-value of the e-WOM variable <table. This indicates that e-WOM provided by other users does not influence the purchase decision. This finding contradicts Zhang, J.Q., Craciun, G., \& Shin, D (2010) that when an exchange of information via e-WOM, consumers will evaluate the product and decide to buy.

The results of this study support research conducted by Wijaya and Paramita (2014) with differences in the study population, research locations and research objects, and the similarity of respondents who dominate the respondents with the student profession. However, this study does not support previous studies conducted by Virenabia and Farah (2018), where there are differences in the study population, research location, and research object. This study also does not support previous studies conducted by Priansa Donni (2016), where there are differences in population and purpose of research.

The results of this study support the theory of Lin et al. (2013) online buyers who tend to wait for e-WOM provided by other users to give an overview of the experience that has been done. This is consistent with items obtained with an average yield of 3.61. Respondents in this study were dominated by respondents with an age range of $22-25$ years as many as $47 \%$ included in generation $Z$, the characteristics of generation $Z$ are strictly related to technology that makes them take information from digital media in their daily lives. But besides making the shopping experience of others as a reference for generation $Z$, the majority of which are still in education, certainly pay more attention to other factors to make purchases such as price, promotion, and quality of service.

The reviews of Tokopedia customers do not represent the complete products/services received. Not all buyers give a review, and not all senders send pictures, so the report is considered less informative. This facts result in eWOM 
does not significantly influence the purchase decision on the Tokopedia application.

Effect of Ease on purchasing decisions

The results showed that there was a significant effect of ease on purchasing decisions. This explains when a system is more straightforward, it will encourage buying decisions, as it is more convenient to use. So this proves the theory put forward by Gefen (2002) that information technology or website is determined by the perceived benefits of users, ease of use.

The results of this study support the research conducted by Ardyanto (2015); Pratama, R. I., Megadini, D. D., \& Kusriandini, T. (2019); Benito Aditiya. (2002) with differences in locations and the number of research samples, research objects. Tokopedia provides an interface feature that makes it easy for users to communicate with sellers or fellow users.

The insignificant effect of e-WOM's on purchasing decisions can also be decided by the rejection of the information received. According to Huang et al. (2012), the influence of eWOM is different from Word of Mouth (WOM) because using online media causes the informers and recipients of information not to meet each other. The interaction is limited to writing comments, from one or several informants. The credibility of some of the informants cannot be approved. This logics could provide the reasonings of the insignificant finding.

\section{Effect of Trust on purchasing decisions}

The results showed that there was a significant influence on trust in purchasing decisions. This means that if user confidence increases, it will drive purchasing decisions. One of the factors that influence purchasing decisions is trust, so this proves the theory put forward by Turban et. Al. That there are three factors that consumer trust can influence purchasing decisions, namely trust in internet traders, trust in the internet as a shopping channel, and believe in the environment business and regulations. So, if the user feels in these three factors, a purchase decision will occur.

The result of this study was in line with Ardyanto et al. (2015), Sfenrianto et. Al (2018), Kore et al. (2018), and Suhardi (2018) with differences in research objects, research locations, and the number of research samples. However, this study was against Wardoyo and Intan (2017). Trust in this study was measured using three indicators, namely integrity, kindness, and ability. Based on the results of the analysis and discussion of this study it can be concluded that of the three independent variables there is one variable that has no significant effect on purchasing decisions, namely the e-WOM variable. Whereas the other two variables namely ease of use and trust have a significant influence on purchasing decisions. Of the two variables that have a significant influence, the ease of use variable has a stronger influence than the trust variable, this implies that users in the current era prefer convenience in daily life because it is more effective and efficient than trusting something. 


\section{FURTHER STUDY}

This study has several weaknesses, namely: (1) This study does not provide an open questionnaire related to e-WOM, ease of use, and trust so that the discussion about them is not in-depth. (2) Researchers are less precise in determining respondents at the beginning of the study, namely students, so the impact on this study will be on the students. Based on the weaknesses of this study, there are several things suggested for further researchers, namely: (1) Deepening statements related to e-WOM, ease of use, and trust so that the discussion can be explained in detail. (2) The next researchers are expected to be more careful in determining the respondent at the beginning.

\section{REFERENCES}

Aldo Fenalosa. (2019). 5 Gambaran Industri E-Commerce Indonesia di Tahun 2019. http:/ /iprice.co.id

Anggraeni, P., \& Madiawati, P. N. (2016). Pengaruh Kepercayaan dan Kualitas Informasi Terhadap Pembelian Secara Online Pada Situs WWW.TRAVELOKA.COM. E-Proceeding of Management:, 3(2), 1880-1887. Ardyanto, D. (2015). Pengaruh Kemudahan Dan Kepercayaan Menggunakan ECommerce Terhadap Keputusan Pembelian Online (Survei Pada Konsumen www.petersaysdenim.com). Jurnal Administrasi Bisnis S1 Universitas Brawijaya, 22(1), 1-8.

Benito Aditiya. (2002). Analisis Pengaruh Kepercayaan, Kemudahan, dan Kualitas informasi Terhadap Keputusan Pembelian Secara Online di KASKUS.

Chen, H. (2012). The Impact Of Comments And Recommendation System On Online Shopper Buying Behaviour. Journal of Networks, 7(2), 345-350.

Cheung, C. M. K., Lee, M. K. O., \& Thadani, D. R. (2009). The impact of positive electronic word-of-mouth on consumer online purchasing decisions. Lecture Notes in Computer Science (Including Subseries Lecture Notes in Artificial Intelligence and Lecture Notes in Bioinformatics), 5736 LNAI, 501-510.

Chin, A. J., Wafa, S. A. W. S. K., \& Ooi, A.-Y. (2009). The Effect of Internet Trust and Social Influence towards Willingness to Purchase Online in Labuan, Malaysia. International Business Research, 2(2), 72-81.

Corritore, C. L., Kracher, B., \& Wiedenbeck, S. (2003). On-line trust: Concepts, evolving themes, a model. International Journal of Human Computer Studies, 58(6), 737-758.

Davis, F. D. (1989). Perceived Usefulness, Perceived Ease of Use, and User Acceptance of Information Technology. Management Information Systems Research Center, University of Minnesota, 13(3), 319-340.

Devaraj, S., Fan, M., \& Kohli, R. (2003). E-loyalty: elusive ideal or competitive edge? Communications of the ACM, 46(9), 184.

Dr. John Eaton. (2006). E-WORD OF MOUTH Marketing. 5, 1-7.

Gefen, D. (2002). Customer Loyalty in E-Commerce. Journal of the Association for Information Systems, 3(1), 27-53.

Hennig-Thurau, T., Gwinner, K. P., Walsh, G., \& Gremler, D. D. (2004). Electronic word-of-mouth via consumer-opinion platforms: What motivates 
consumers to articulate themselves on the internet? Journal of Interactive Marketing, 18(1), 38-52.

Kim, D. J., Ferrin, D. L., \& Rao, H. R. (2008). A trust-based consumer decisionmaking model in electronic commerce: The role of trust, perceived risk, and their antecedents. Decision Support Systems, 44(2), 544-564.

Kore, E. L. R., Lamalewa, F., \& Mulyaningsih, A. (2018). The influence of promotion, trust, and convenience to online purchase decisions. International Journal of Mechanical Engineering and Technology, 9(10), 7783.

Kotler, Philip \& Keller Kevin Lane. 2009. Manajemen Pemasaran Edisi Ketiga Belas Jilid 1 dan Jilid 2. Erlangga.

Lin, C., Wu, Y.-S., \& Chen, J.-C. V. (2013). Electronic Word-of-Mouth: The Moderating Roles of Product Involvement and Brand Image. Proceedings of 2013 International Conference on Technology Innovation and Industrial Management, 29-47.

Mahkota, A. P., Suyadi, L., Riyadi. (2014). Pengaruh Kepercayaan dan Kenyamanan Terhadap Keputusan Pembelian Online. Administrasi Bisnis. Vol. 8(2): hal. 1-7.

Malhotra, K. Naresh. 2009. Riset Pemasaran Pendekatan Terapan Edisi Keempat Jilid 1. Jakarta: PT Indeks.

Martina Monisa. (2013). Persepsi Kemudahan Dan Kegunaan Opac Perpustakaan Unair. Universitas Airlangga, 2(1), 1-6.

Mayer, R. C., Davis, J. H., \& Schoorman, F. D. (1995). Model of Trust Theory. The Academy of Management Review, 20(3), 709-734.

McKnight, D. H., Choudhury, V., \& Kacmar, C. (2002). Developing and validating trust measures for e-commerce: An integrative typology. Information Systems Research, 13(3), 334-359.

Moorman, C., Zaltman, G., \& Deshpande, R. (1992). Relationships between Providers and Users of Market Research: The Dynamics of Trust within and between Organizations. Journal of Marketing Research, 29(3), 314.

Park, D. H., \& Kim, S. (2008). The effects of consumer knowledge on message processing of electronic word-of-mouth via online consumer reviews. Electronic Commerce Research and Applications, 7(4), 399-410. https:// doi.org/10.1016/j.elerap.2007.12.001.

Pratama, R. I., Megadini, D. D., \& Kusriandini, T. (2019). Effect of Perceived Ease of Use, Word-of-Mouth Communication, and Brand Image on Decision to Use Lazada E-Commerce Services. International Journal of Multicultural and Multireligious Understanding, 6(1), 173.

Priansa, D. J. (2016). Pengaruh E-Wom dan Persepsi Nilai terhadap Keputusan Konsumen untuk Berbelanja Online di Lazada. Jurnal Ecodemica: Jurnal Ekonomi, Manajemen, Dan Bisnis, 4(1), 117-124.

Puntoadi, Danis, 2011. Menciptakan Penjualan Melalui Social Media, PT Elex Komputindo, Jakarta.

Pusparisa, Y. (2019). 96\% Pengguna Internet di Indonesia Pernah Menggunakan E-commerce. 
Putro, H. B. \& Haryanto, B. (2015). Factors Affecting Purchase Intention of Online Shopping in Zalora Indonesia. British Journal of Economics, Management \& Trade.

Romla, S., \& Ratnawati, A. (2018). Keputusan Pembelian E-Commerce Melalui Kemudahan Penggunaan, Kualitas Informasi Dan Kualitas Interaksi Layanan Web. Jurnal Ekonomi Dan Bisnis, 19(1), 59.

Sari, N., Saputra, M., \& Husein, J. (2017). Pengaruh Electronic Word of Mouth Terhadap Keputusan Pembelian Pada Toko Online Bukalapak.Com. Jurnal Manajemen Magister, 03(01), 96-106.

Schiffman, Leon G.And Leslie L. Kanuk. 2000. Consumer Behavior. Fifth Editions, Prentice-Hall Inc. New Jersey.

Senecal, S., \& Nantel, J. (2004). The influence of online product recommendations on consumers' online choices. Journal of Retailing, 80(2), 159-169.

Sfenrianto, Gunawan, W., Kelly, D. S., \& Tarigan, R. E. (2018). The use of quality, security, and trust factors to improve the online purchase decision. Journal of Theoretical and Applied Information Technology, 96(5), 1436-1445.

Suhardi, D., \& Taufik, N. (2018). The Analysis of Ease of Use, Trust, and Website Quality towards Purchasing Decision in Lazada.co.id. Indonesian Journal Of Business And Economics, 1(1), 38-48.

Sumarwan, Ujang. 2014. Perilaku Konsumen Teori dan Penerapan (Edisi Kedua). Ghalia Indonesia. Bogor.

Tim Penyusun Buku Pedoman Penulisan Skripsi. (2018). Pedoman Penulisan Skripsi. Surabaya: Universitas Negeri Surabaya.

Top Brand Index Beserta Kategori Lengkap | Top Brand Award. (n.d.). Diakses pada 26 Januari, 2020, from https:/ / www.topbrand-award.com/top-brandindex

Turban, Efraim, David King, Dennis Viehland, Jae Lee. (2010). Electronic Commerce a Managerial Perspective Eight Edition.

Venkatesh, V., \& Davis, F. D. (2000). A theoretical extension of the Technology Acceptance Model: Four longitudinal field studies. Management Science, 46(2), 186-204.

Virenabia, C., \& Oktafani, F. (2018). Pengaruh Electronic Word Of Mouth ( EWOM ) Sebagai Media Promosi Terhadap Minat Beli Pada Followers Instagram Bandung Makuta. E-Proceeding of Management, 5(1), 1000-1009.

Wardoyo, \& Andini, I. (2017). Sosial Facebook Dalam Penerapan Strategi Promosi Penjualan Online Shop. Jurnal Manajemen Daya Saing, 19(1), 1226.

Wijaya, T., \& Paramita, L. E. (2014). Pengaruh Electronic Word of Mouth (EWoM) terhadap Keputusan Pembelian Kamera DSLR. Econimics and Business, 9(Sancall), 12-19.

Yohanes Suhari. (2008). Keputusan Membeli Secara Online dan Faktor-Faktor yang Mempengaruhinya. Jurnal Teknologi Informasi DINAMIK, XIII(2), 140-146.

Zhang, J. Q., Craciun, G., \& Shin, D. (2010). When does electronic word-of-mouth matter? A study of consumer product reviews. Journal of Business Research, 63(12), 1336-1341. 